\title{
THE USE OF INCOMPLETE FAMILY DATA IN THE ANALYSIS OF GENETICS AND SELECTION AT THE Ng LOCUS IN BLUE GROUSE (DENDRAGAPUS OBSCURUS)
}

\author{
J. A. REDFIELD* \\ Department of Zoology, University of Alberta, Edmonton, Alberta, Canada \\ Received 11.viii.72
}

\begin{abstract}
SUMMary
Incomplete family data were used to show the inheritance of the $\mathrm{Ng}$ locus in blue grouse. Three bands found on starch-gels were inherited as codominant alleles at a single autosomal locus. Mothers were in Hardy-Weinberg equilibrium. Chicks had two significant departures from equilibrium conditions but these were in opposite directions. Heterozygous females, $\mathrm{NgS} / \mathrm{NgM}$, produced too few heterozygous and rare homozygous, $\mathrm{NgS} / \mathrm{NgS}$, offspring. This deviation was not found among offspring from homozygous mothers. These results may be due to a phenomenon known as the unlike-homozygous-parent effect in cattle. No mechanism is known to account for these results. These analyses suggest that fitness is a complex function of different types of selection at different times in the year.
\end{abstract}

\section{INTRODUCTION}

Cooper (1966, 1968; Cooper and Rendel, 1968) has pointed out the utility of incomplete family data in the analysis of genetics and selection in populations. Formally, incomplete family data (IFD) are genetic data where the genotypes of one parent and one or more offspring are known. IFD have the advantage over population data in that they allow one to test hypotheses about inheritance and detect the effects of selection and population subdivision (the Wahlund effect, Wahlund, 1928). IFD are usually easier to collect than complete family data and may be the only data available from most natural populations.

Cooper (1968) urged the collection of IFD from marsupials and domestic species of mammals. Manwell and Baker (1970, p. 24) state that IFD can only be collected from viviparous or ovoviviparous vertebrates. These authors seem to have overlooked the possible source of information obtainable from birds. In many birds, including blue grouse, a mother and young are closely associated for some time and this association leads to the possible collection of IFD.

This paper is an analysis of IFD from the $\mathcal{N g}$ locus in blue grouse living on Vancouver Island, British Columbia. The $\mathcal{N g}$ locus was previously described by Birdsall et al. (1970) and appears as white bands on starch-gels stained for serum esterase (fig. 1). No other breeding data are available to test the inheritance of variants at this locus in blue grouse and the data will be used to establish the mode of inheritance at this locus. In addition, an analysis of selection in young blue grouse will be done. Other questions that I will attempt to answer will be: (1) Do males and females breed at random

- Present address: Institute of Animal Resource Ecology, University of British Columbia, Vancouver 8, B.C., Canada. 


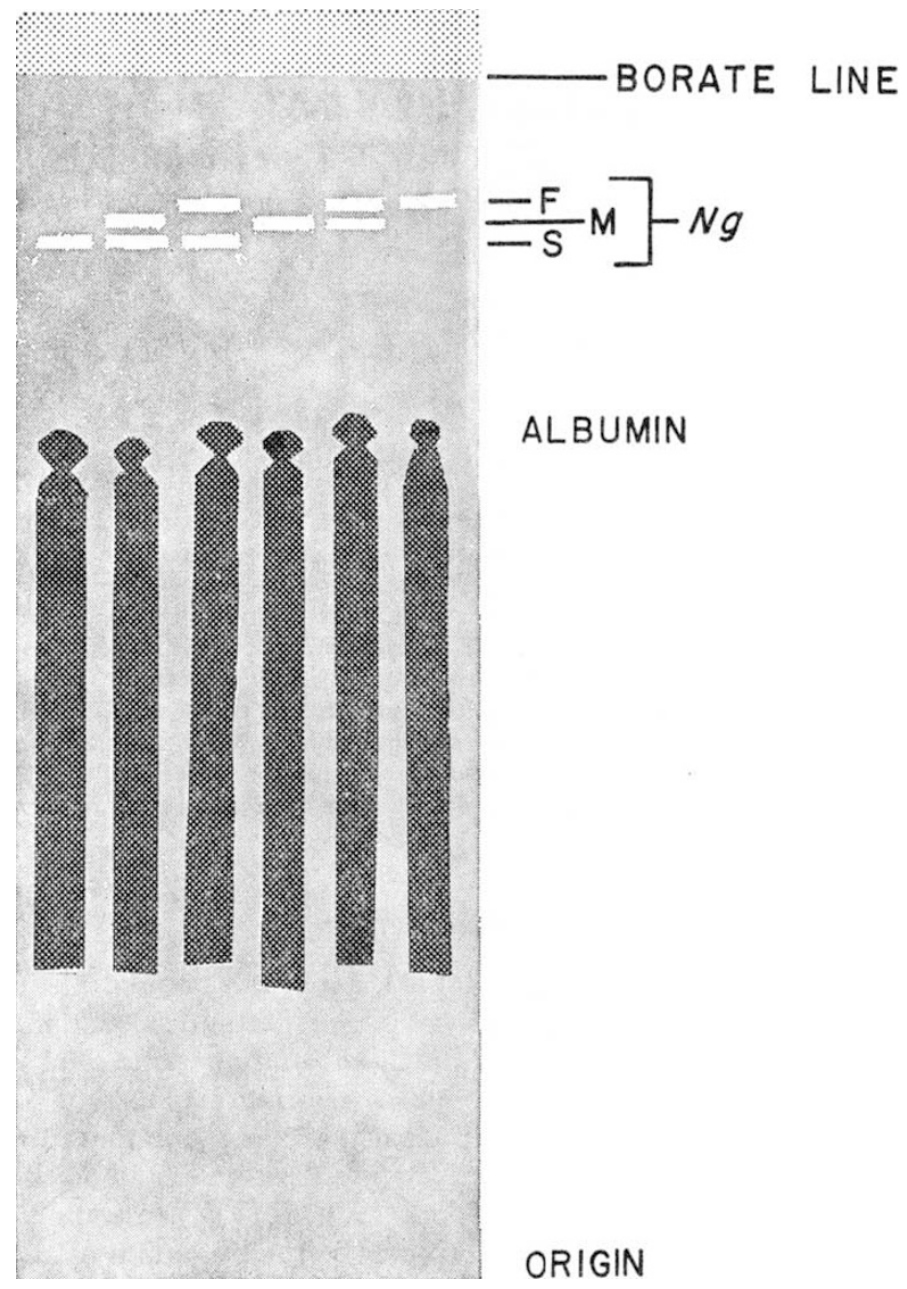

Frg. 1.-Diagrammatic representation of the six phenotypes found at the $\mathrm{Ng}$ locus in blue grouse. From left to right these phenotypes are $\mathrm{NgS} / \mathrm{NgS}, \mathrm{NgS} / \mathrm{NgM}, \mathrm{NgS} / \mathrm{NgF}$, $\mathcal{N g} M / N g M, N g M / N g F, N g F / N g F$. Darker areas represent areas of esterase activity.

with respect to this locus? and (2) Is there evidence for differential fertility among genotypes of females?

\section{Methods}

Blue grouse were captured from wild populations on Vancouver Island, near Port Alberni, British Columbia. All birds were bled by puncturing a small vein on the ventral surface of the wing. All chicks reported in this paper were less than 25 days of age and most were less than 10 days old. Cells were separated from plasma and both were frozen at $-20^{\circ} \mathrm{C}$. or colder until analysed. Starch-gel electrophoresis (Smithies, 1955, 1959) of plasma was used to separated the proteins. A discontinuous system of buffers (Poulik, 1957) was used: 
Bridge buffer: a litre water and $3.6 \mathrm{~g}$. boric acid and $4.0 \mathrm{~g}$. lithium hydroxide;

Gel buffer: a litre water and $2 \cdot 0 \mathrm{~g}$. citric acid, $7 \cdot 0 \mathrm{~g}$. tris, and $170 \mathrm{ml}$. bridge buffer.

This is modified after Fujino and Kang (1968). Vertical electrophoresis was carried out at $2^{\circ} \mathrm{C}$. with a constant voltage of 400 volts and a current of $2 \mathrm{ma} . / \mathrm{cm}$. gel at the start. Electrophoresis was for about 4 hours, but was allowed to proceed until the borate buffer had migrated $16 \mathrm{~cm}$. This was important since the $\mathcal{N g}$ system was not visible until the borate buffer had migrated through it.

After electrophoresis, gels were stained for 2 hours in dark in a solution commonly used for detecting esterases: $0.95 \mathrm{~g}$. $\alpha$-naphthyl acetate (dissolved in $2.5 \mathrm{ml}$. acetone), $10 \mathrm{ml}$. of $0.1 \mathrm{M}$ Tris-HGI buffer $(p \mathrm{H} \mathrm{7.0})$, and $250 \mathrm{mg}$. Fast-blue RR salt were added to $90 \mathrm{ml}$. of water and mixed a couple of minutes prior to staining. Following staining, gels were washed for 24 to 48 hours in methanol, water and acetic acid (5:5:1). Bands were visible anodal to the major albumin esterase activity as white areas on a blue background (plate I). This method is modified from that reported in Birdsall, Redfield and Cameron (1970).

\section{Results}

Three white bands have been detected after electrophoresis of plasma from blue grouse. All individuals scored had at least one band but none had more than two bands. Plasma from the same bird bled at two different times invariably produced the same pattern. Since systems with these characteristics have been found to be inherited by means of codominant alleles at a single autosomal locus (Manwell and Baker, 1970) and since there was close agreement to Hardy-Weinberg expectations based on this hypothesis, it was reasonable to assume that these bands were products of three codominant autosomal alleles, $\mathcal{N g F}, \mathcal{N g} M$ and $\mathcal{N g S}$, for the fastest, intermediate and slowest bands, respectively (fig. 1). There is confusion concerning nomenclature in spite of Ashton's et al. (1967) plea for standardisation. I have followed the suggestions of Baker et al. (1970). All six possible genotypes from these three alleles have been found. Homozygotes were characterised by having a single band and heterozygotes by having two bands.

$\mathcal{N g} M$ was by far the most common allele with a frequency of near 0.8 in most populations. Because of the rarity of $\mathcal{N g F}$, it will be considered equivalent to $\mathcal{N g S}$ for most analyses. Most populations examined have been in Hardy-Weinberg equilibrium and the three alleles are widespread in blue grouse on Vancouver Island (Redfield et al., 1972). Thus, the polymorphism appears stable (Ford, 1965).

The method using IFD is based on the fact that among parents of known genotypes there are certain expectations of genotypes among offspring. These expectations are presented in table 1 in the form of an idealised IFD table with no selection or population subdivision. In this table there are two alleles, $A$ and $B$, at a single autosomal locus, with frequencies $p$ and $q$ in the parent generation. Offspring are represented as $O$ and subscripts are used to denote parent genotype and offspring genotype, respectively. Thus,

$$
31 / 1-\mathrm{C}_{2}
$$


TABLE 1

Idealised incomplete family data table when there is no population subdivision or selection. Subscripts appended to 0 signify parental and offspring genotype respectfully

Parental genotypes and their frequencies

Frequencies of genotypes among offspring

\begin{tabular}{|c|c|c|c|c|c|}
\hline Female & Male & $A A$ & $A B$ & $B B$ & Total \\
\hline $\begin{array}{l}A A \\
p^{2}\end{array}$ & $\begin{array}{l}A A \\
p^{2}\end{array}$ & $p^{4}$ & - & - & \\
\hline $\begin{array}{l}A A \\
p^{2}\end{array}$ & $\begin{array}{l}A B \\
2 p q\end{array}$ & $p^{8} q$ & $p^{\mathbf{s}} q$ & - & \\
\hline $\begin{array}{l}A A \\
p^{2}\end{array}$ & $\begin{array}{l}B B \\
q^{2}\end{array}$ & - & $p^{2} q^{2}$ & - & \\
\hline $\begin{array}{l}A A \\
p^{2}\end{array}$ & $?$ & $\begin{array}{l}p^{3} \\
{\left[O_{A . A}\right]}\end{array}$ & $\begin{array}{c}p^{2} q \\
{\left[\mathrm{O}_{A \cdot A B}\right]}\end{array}$ & & {$\left[\begin{array}{c}p^{2} \\
{\left[O_{A .}\right]}\end{array}\right.$} \\
\hline $\begin{array}{l}A B \\
2 p q\end{array}$ & $\begin{array}{l}A A \\
p^{2}\end{array}$ & $p^{2} q$ & $p^{\mathbf{2}} q$ & - & \\
\hline $\begin{array}{l}A B \\
p q\end{array}$ & $\begin{array}{l}A B \\
2 p q\end{array}$ & $p^{2} q^{2}$ & $2 p^{2} q^{2}$ & $p^{2} q^{2}$ & \\
\hline $\begin{array}{l}A B \\
2 p q\end{array}$ & $\begin{array}{l}B B \\
q^{8}\end{array}$ & - & $p q^{8}$ & $p q^{3}$ & \\
\hline $\begin{array}{l}A B \\
2 p q\end{array}$ & $?$ & $\begin{array}{c}p^{2} q \\
{\left[\mathrm{O}_{A B \cdot A}\right]}\end{array}$ & $\stackrel{p q}{\left[\mathrm{O}_{A B, A B}\right]}$ & $\begin{array}{c}p q^{2} \\
{\left[\mathrm{O}_{A B, B}\right]}\end{array}$ & $\begin{array}{c}2 p q \\
{\left[\mathrm{O}_{A B} .\right]}\end{array}$ \\
\hline $\begin{array}{l}B B \\
q^{2}\end{array}$ & $\begin{array}{l}A A \\
p^{2}\end{array}$ & - & $p^{2} q^{2}$ & - & \\
\hline $\begin{array}{l}B B \\
q^{2}\end{array}$ & $\begin{array}{l}A B \\
2 p q\end{array}$ & - & $p q^{8}$ & $p q^{8}$ & \\
\hline $\begin{array}{l}B B \\
q^{2}\end{array}$ & $\begin{array}{l}B B \\
q^{8}\end{array}$ & - & - & $q^{4}$ & \\
\hline $\begin{array}{l}B B \\
q^{2}\end{array}$ & $?$ & - & $\begin{array}{c}p q^{2} \\
{\left[\mathrm{O}_{B . A B}\right]}\end{array}$ & $\begin{array}{l}q^{8} \\
{\left[\mathrm{O}_{B . B}\right]}\end{array}$ & $\begin{array}{l}q^{2} \\
{\left[\mathrm{O}_{B .}\right]}\end{array}$ \\
\hline Totals & & $\begin{array}{l}p^{2} \\
{[0.1]}\end{array}$ & $\begin{array}{l}2 p q \\
{[O . A B]}\end{array}$ & $\begin{array}{l}q^{2} \\
{[O . B]}\end{array}$ & 1 \\
\hline
\end{tabular}

$\mathrm{O}_{A, A B}$ denotes an $A B$ offspring born from an $A A$ parent. From this table it can be shown that the following are expectations in an idealised population:

$$
\begin{aligned}
& \frac{\left(\mathrm{O}_{A B . A}+\mathrm{O}_{A B \cdot B}\right)}{\mathrm{O}_{A B . A B}}=\frac{1}{1} \\
& \frac{\mathrm{O}_{A . A}}{\mathrm{O}_{A . A B}}=\frac{\mathrm{O}_{A B . A}}{\mathrm{O}_{A B . B}}=\frac{\mathrm{O}_{B \cdot A B}}{\mathrm{O}_{B . B}}=\frac{p}{q} .
\end{aligned}
$$

The first ratio is the 1:1 ratio and the next three the gametic gene ratios (Cooper, 1968). Several different $\chi^{2}$ goodness-of-fit tests can be carried out on these ratios to detect selection and population subdivision. 


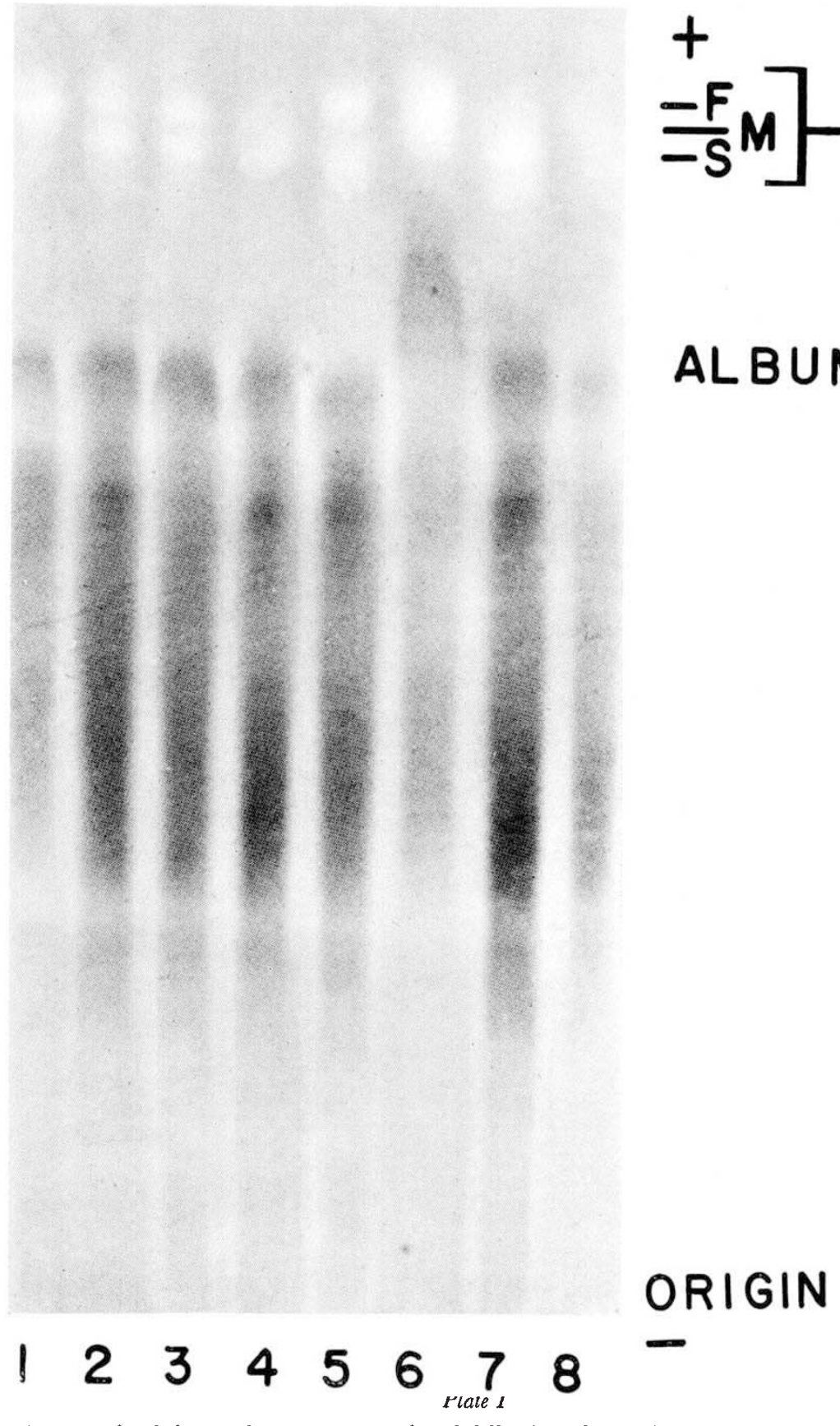

Photograph of the $\mathcal{N g}$ locus on a starch gel following electrophoresis of plasma from blue grouse. The phenotypes here correspond to the genotypes: (1) $\mathcal{N g} M / \mathcal{N g}$; (2) $\mathcal{N g} M / \mathcal{N g S}$; (3) $\mathcal{N g} M / \mathcal{N g S}$; (4) $\mathcal{N g} M / \mathcal{N g S}$; (5) $\mathcal{N g} F / \mathcal{N g S}$; (6) $\mathcal{N g F} / \mathcal{N g} M$; (7) $\mathcal{N g} M / \mathcal{N g S}$; (8) $\mathcal{N g} M / \mathcal{N g} M$. Lighter white bands were found in some samples but these had no genetic significance. 
The 1:1 ratio will only be affected by selection operating on zygotes, while the gametic gene ratios will be affected by gametic selection, zygotic selection, and population subdivision. The pattern of results obtained should indicate which is operating.

IFD collected from 1969 through 1971 are presented in table 2. The frequency of genotypes among mothers had no significant departures from Hardy-Weinberg expectations (table 3). Genotypes of chicks, however, had two significant departures: in 1969 there was a significant deficiency of heterozygotes and in 1970 there was a significant excess (table 3 ). There were no departures from expectations in 1971, nor were there any significant departures from expectations when the data were combined for all years. The

TABLE 2

Incomplete family data collected from female blue grouse and their offspring on Vancouver Island, 1969-1971 The allele NgF is combined with NgS

\begin{tabular}{|c|c|c|c|c|}
\hline \multirow[b]{2}{*}{ Year } & \multirow{2}{*}{$\begin{array}{l}\text { Mother's } \\
\text { genotype }\end{array}$} & \multicolumn{3}{|c|}{ Offspring genotypes } \\
\hline & & $\mathcal{N g S} / \mathcal{N}_{g} S$ & $\mathcal{N g S} / \mathcal{N g M}$ & $\mathcal{N g} M / N g M$ \\
\hline 1969 & $\begin{array}{l}\mathcal{N g S} / \mathcal{N g S} \\
\mathcal{N g S} / \mathcal{N g} M \\
\mathcal{N g} M / \mathcal{N g} M\end{array}$ & $\begin{array}{r}3 \\
4 \\
-\end{array}$ & $\begin{array}{l}3 \\
4 \\
8\end{array}$ & $\begin{array}{r}\overline{7} \\
25\end{array}$ \\
\hline 1970 & $\begin{array}{l}\mathcal{N g S} / \mathcal{N g S} \\
\mathcal{N g S} / \mathcal{N g} M \\
\mathcal{N g} M / \mathcal{N g} M\end{array}$ & $\begin{array}{c}1 \\
3 \\
-*\end{array}$ & $\begin{array}{r}7 \\
19 \\
61\end{array}$ & $\begin{array}{l}\overline{27}^{*} \\
88\end{array}$ \\
\hline 1971 & $\begin{array}{l}\mathcal{N g S} / \mathcal{N g S} \\
\mathcal{N g S} / \mathcal{N g M} \\
\mathcal{N g} M / \mathcal{N g} M\end{array}$ & $\begin{array}{r}3 \\
9 \\
-\end{array}$ & $\begin{array}{r}7 \\
42 \\
41\end{array}$ & $\begin{array}{c}\bar{C}^{*} \\
58 \\
195\end{array}$ \\
\hline Totals & $\begin{array}{l}\mathcal{N g S} / \mathcal{N g S} \\
\mathcal{N g S} / \mathcal{N g} M \\
\mathcal{N g} M / \mathcal{N g} M\end{array}$ & $\begin{array}{r}7 \\
16 \\
-\end{array}$ & $\begin{array}{r}17 \\
65 \\
110\end{array}$ & $\begin{array}{r}\overline{92} \\
308\end{array}$ \\
\hline
\end{tabular}

* The single offspring which belonged to each of these cells was not compatible with genetic theory. These individuals have been excluded from all further analyses.

two deviations found in chicks in 1969 and 1970 tended to cancel each other out so that totals for chicks are in almost perfect equilibrium.

Results of tests made on IFD for agreement with the $1: 1$ ratio are given in table 4. In all years heterozygous mothers produced an excess number of homozygous offspring. In 1971 and in the totals for years combined, these differences were significant. This excess of homozygotes was due to zygotic selection against heterozygous offspring.

Gametic gene ratios were tested and results are presented in table 5 . These were tests of the gametic ratios among male parents. There were no significant departures from expectations in 1969 or 1971. In 1970 there was a significant deficiency of rare homozygotes produced by heterozygous parents. In all years heterozygotes tended to produce too few rare homozygotes, resulting in the totals being significantly different from expectations.

Based on these results it seems safe to conclude that departures from expectations in both the 1:1 tests and the gametic gene ratio tests have been caused by selection against heterozygous and rare homozygous offspring of 
TABLE 3

Observed and expected genotypic frequencies of mothers and offspring. Expectations were based on Levene's exact formulae for Hardy-Weinberg proportions (Dobzhansky and Levene, 1948). $\mathcal{N}$ is the sample size, $p$ is the frequency of $\mathrm{NgM}$, and probability is the exact probability of observing this distribution by chance alone.

\begin{tabular}{|c|c|c|c|c|c|c|c|}
\hline Year & Group & $\mathbf{N}$ & $\mathcal{N}_{g} S / \mathcal{N}_{g} S$ & $\mathcal{N g}_{\mathrm{g}} S / \mathcal{N g}_{\mathrm{g}} \mathrm{M}$ & $\mathcal{N}_{g} M / \mathcal{N}_{g} M$ & $p$ & Probability \\
\hline 1969 & $\begin{array}{l}\text { Adults } \\
\text { Chicks }\end{array}$ & $\begin{array}{l}\text { Obs. } 41 \\
\text { Exp. } \\
\text { Obs. } 54 \\
\text { Exp. }\end{array}$ & $\begin{array}{l}0.073 \\
0.055 \\
0.130 \\
0.068\end{array}$ & $\begin{array}{l}0.341 \\
0.378 \\
0.278 \\
0.400\end{array}$ & $\begin{array}{l}0.585 \\
0.567 \\
0.593 \\
0.531\end{array}$ & 0.756 & 0.52 \\
\hline 1970 & $\begin{array}{l}\text { Adults } \\
\text { Chicks }\end{array}$ & $\begin{array}{l}\text { Obs. } 72 \\
\text { Exp. } \\
\text { Obs. } 206 \\
\text { Exp. }\end{array}$ & $\begin{array}{l}0.042 \\
0.026 \\
0.019 \\
0.052\end{array}$ & $\begin{array}{l}0.250 \\
0.282 \\
0.422 \\
0.357\end{array}$ & $\begin{array}{l}0.708 \\
0.692 \\
0.558 \\
0.591\end{array}$ & $\begin{array}{l}0.833 \\
0.769\end{array}$ & $\begin{array}{l}0.32 \\
0.001\end{array}$ \\
\hline 1971 & $\begin{array}{l}\text { Adults } \\
\text { Chicks }\end{array}$ & $\begin{array}{l}\text { Obs. } 129 \\
\text { Exp. } \\
\text { Obs. } 355 \\
\text { Exp. }\end{array}$ & $\begin{array}{l}0.031 \\
0.032 \\
0.034 \\
0.025\end{array}$ & $\begin{array}{l}0.302 \\
0.300 \\
0.254 \\
0.270\end{array}$ & $\begin{array}{l}0.667 \\
0.668 \\
0.713 \\
0.704\end{array}$ & $\begin{array}{l}0.818 \\
0.839\end{array}$ & $\begin{array}{l}0.94 \\
0.24\end{array}$ \\
\hline Total & $\begin{array}{l}\text { Adults } \\
\text { Chicks }\end{array}$ & $\begin{array}{l}\text { Obs. } 242 \\
\text { Exp. } \\
\text { Obs. } 615 \\
\text { Exp. }\end{array}$ & $\begin{array}{l}0.041 \\
0.035 \\
0.037 \\
0.037\end{array}$ & $\begin{array}{l}0.293 \\
0.307 \\
0.312 \\
0.313\end{array}$ & $\begin{array}{l}0.665 \\
0.659 \\
0.650 \\
0.650\end{array}$ & $\begin{array}{l}0.812 \\
0.807\end{array}$ & $\begin{array}{l}0.50 \\
0.97\end{array}$ \\
\hline
\end{tabular}

TABLE 4

Results of $\chi^{2}$ goodness-of -fit tests for the $1: 1$ ratio on offspring from heterozygous mothers. $\chi^{2}$ corrected for continuity with Yate's correction. $0_{A B, A B}: 0_{A B, A}+0_{A B, B}=1: 1$

$\begin{array}{lccl}\text { Year } & \text { Observed numbers } & \chi^{2} & P \leqq \\ 1969 & 4: 11 & 2 \cdot 4 & 0.12 \\ 1970 & 19: 30 & 2 \cdot 0 & 0.15 \\ 1971 & 42: 67 & 5 \cdot 3 & 0.02 \\ \text { Total } & 65: 108 & 10 \cdot 2 & 0.001\end{array}$

TABLE 5

$\chi^{2}$ tests for heterogeneity of male gametic gene ratios for the $\mathrm{Ng}$ locus in blue grouse

\begin{tabular}{|c|c|c|c|c|c|}
\hline Year & Ratio tested & $\begin{array}{l}\text { Observed } \\
\text { numbers }\end{array}$ & $x^{2}$ & d.f. & $\mathrm{P} \leqq$ \\
\hline 1969 & $\begin{array}{l}\text { (1) } 0_{A \cdot A}: 0_{A \cdot A B} \\
\text { (2) } 0_{A B \cdot A}: 0_{A B \cdot B} \\
\text { (3) } 0_{B \cdot A B}: 0_{B \cdot B}\end{array}$ & $\begin{array}{l}3: 3 \\
4: 7 \\
8: 25\end{array}$ & $\begin{array}{l}1 \cdot 05 \\
0.2 \\
0.5\end{array}$ & $\begin{array}{l}1 \\
1 \\
1\end{array}$ & $\begin{array}{l}0.3 \\
0.7 \\
0.5\end{array}$ \\
\hline 1970 & $\begin{array}{l}(1) \\
(2) \\
(3)\end{array}$ & $\begin{array}{c}1: 7 \\
3: 27 \\
61: 88\end{array}$ & $\begin{array}{l}2 \cdot 1 \\
9 \cdot 9 \\
2 \cdot 5\end{array}$ & $\begin{array}{l}1 \\
1 \\
1\end{array}$ & $\begin{array}{l}0.15 \\
0.002 \\
0.12\end{array}$ \\
\hline 1971 & $\begin{array}{l}(1) \\
(2) \\
(3)\end{array}$ & $\begin{array}{c}3: 7 \\
9: 58 \\
41: 195\end{array}$ & $\begin{array}{l}1 \cdot 0 \\
0 \cdot 6 \\
0 \cdot 03\end{array}$ & $\begin{array}{l}1 \\
1 \\
1\end{array}$ & $\begin{array}{l}0.3 \\
0.4 \\
0.9\end{array}$ \\
\hline Total & $\begin{array}{l}\text { (1) } \\
(3) \\
(3)\end{array}$ & $\begin{aligned} 7: 17 \\
16: 92 \\
110: 308\end{aligned}$ & $\begin{array}{l}0 \cdot 32 \\
5 \cdot 7 \\
1 \cdot 1\end{array}$ & $\begin{array}{l}1 \\
1 \\
1\end{array}$ & $\begin{array}{l}0.6 \\
0.02 \\
0.3\end{array}$ \\
\hline
\end{tabular}


heterozygous females. Segregation distortion can be eliminated as a possibility, since it can be shown that this will not alter the expectations in the $1: 1$ tests. Also, failure to find significant departures in the gametic tests on homozygous parents eliminates both misclassification and overall selection against heterozygotes. Thus, selection favours the most common homozygous genotype only from heterozygous mothers.

\section{Discussion}

Incomplete family data are relatively easy to collect and can yield important information about selection in natural populations. Using these data it has been possible to demonstrate selection against heterozygous offspring from heterozygous mothers. This selection cannot be detected using the method of comparing the observed frequency of offspring to HardyWeinberg equilibrium conditions.

Despite the ease of collection, such data for many wild species of animals are rare. Cooper and Rendel (1968) have used the method to analyse selection and population structure in domestic cattle and Niece and Kracht (1967) used the method to analyse selection in domestic burros. The only other published information I am aware of on natural populations is on kangaroos (Cooper and Sharman, 1964) and on Peromyscus (Birdsall, 1972).

Blue grouse are probably polygamous (Bendell and Elliott, 1967) and it is conceivable that one male could mate with many females. Thus, the number of males contributing to future generations may be smaller than the number of females. If true, there should be greater variation in gametic gene ratios among males than females. The available data are limited, but suggest that there may be greater fluctuations in male gene frequencies than in female frequencies. The total range in gene frequencies among male gametes was $0 \cdot 15$ while among female gametes it was $0 \cdot 07$. Thus, it appears likely that fewer males than females contribute to a given generation.

Although rare homozygotes and heterozygotes from heterozygous parents were selected against, total zygotic output of different types of females were the same. The average number of offspring typed per female was 2.5, 2.5 and 2.6 for $\mathcal{N g S} / \mathcal{N g S}, \mathcal{N g S} / \mathcal{N g} M$ and $\mathcal{N g} M / \mathcal{N g} M$, respectively. Thus, although selection operates against some offspring from heterozygous mothers, there appears to be a compensatory excess of common homozygous offspring produced by heterozygotes.

Numerous data are available concerning altered zygotic ratios in domestic cattle. Ashton (1965) showed what appeared to be a superiority of heterozygotes at the $T f$ locus, in utero, but Cooper and Rendel (1968) were unable to confirm this. However, there is a phenomenon in cattle which has been called the UHM effect (unlike-homozygous-mother effect of Cooper and Rendel, 1968). In matings involving heterozygous fathers and homozygous mothers there is a significant excess of offspring with the genotype of the female. No mechanism is known to account for this effect in cattle.

A similar phenomenon could be operating in grouse and could account for the significant departures. Of course, in grouse the effect would have to be an unlike-homozygous-father effect. Until more is known about the biochemistry and function of the $\mathcal{N g}$ locus, further speculation as to the mechanism involved would be frivolous.

If common homozygotes are favoured as chicks, one might expect 
fixation of the more common allele. Yet this polymorphism is widespread on Vancouver Island and all populations have about the same allele frequencies (Redfield et al., 1972). It seems likely that there is selection for heterozygotes at some later stage in the life-cycle.

Acknowledgments.-Financial support was received from the National Research Council of Canada, American Ornithological Union (Josselyn Van Tyne Memorial Grant), British Columbia Fish and Wildlife Branch, and the University of Alberta. MacMillan-Bloedel Ltd., Sproat Lake Division, and their personnel, extended permission to study grouse on their land, use their roads, and work during periods of high fire hazard. Several field assistants aided in the collection of the data. Dr R. P. Canham and Dr F. G. Zwickel made comments on the manuscript and improved its presentation. Thanks are extended to all of these agencies and persons for this assistance.

\section{REFERENCES}

Astron, o. c. 1965. Serum transferrin D alleles in Australian cattle. Aust. F. Biol. Sci., $18,665-670$.

Ashton, G. C., GILMOUR, D. C., KIDDY, C. A., AND KRIstjansson, P. x. 1967. Proposals on nomenclature of protein polymorphisms in farm livestock. Genetics, 56, 353-362.

BAKER, C. M. A., GROIZER, G., STRATIL, A., AND MANWELL, C. 1970. Identity and nomenclature of some protein polymorphisms of chicken eggs and sera. In E. W. Caspari (ed.), Advances in Genetics, pp. 147-174. Academic Press, New York.

BENDELL, J. F., AND ELLIOTT, P. W. 1967. Behaviour and the regulation of numbers in blue grouse. Can. Wildl. Ser. Rep. Series, No. 4. 76 pp. Queen's Printer, Ottawa.

BIRDsalL, D. A. 1972. Allele and phenotype frequency variation of three loci in natural populations of deer mice (Peromyscus maniculatus). $112 \mathrm{pp}$. Unpublished. Ph.D. Thesis, University of Alberta.

BIRDSALL, D. A., REDPIELD, J. A., AND CAMERON, D. G. 1970. White bands on starch-gels stained for esterase activity: A new polymorphism. Biochem. Genet., 4, 655-658.

COOPER, D. W. 1966. A note on the examination of genotypic ratios in domestic animals using incomplete family data. Anim. Prod., 8, $511-513$.

COOPER, D. W. 1968. The use of incomplete family data in the study of selection and population structure in marsupials and domestic animals. Genetics, 60, 147-156.

COOPER, D. W., AND RENDEL, J. 1968. Incomplete family data, selection and population studies of transferrins and blood groups in cattle. Heredity, 23, 49-66.

COOPER, D. W., AND sharman, G. B. 1964. Transferrin variation in kangaroos. Nature, 203, 1094.

Dobzhansky, T., AND LEVEne, H. 1948. Genetics of natural populations. XVII. Proof of operation of natural selection in wild populations of Drosophila pseudoobscura. Genetics, $33,537-547$.

FORD, E. B. 1965. Ecological Genetics, 2nd edition. 335 pp. Methuen, London.

FUjINO, K., AND KANG, T. 1968. Serum esterase groups of Pacific and Atlantic tunas. Copeia, 1, 56-63.

manWell, C., AND baker, c. M. A. 1970. Molecular Biology and the Origin of Species. $394 \mathrm{pp}$. University of Washington Press, Seattle.

NIECE, R. L., AND KRACHT, D. W. 1967. Genetics of transferrins in burros (Equus asinus). Genetics, 57, 837-841.

POULIK, M. 1957. Starch-gels electrophoresis in a discontinuous system of buffers. Nature, $180,1477-1479$.

REDPIELD, J. A., ZWICKel, F. C., BeNDELl, J. P., AND Bergerud, A. T. 1972. Temporal and spatial patterns of allele and genotype frequencies at the $\mathcal{N g}$ locus in blue grouse (Dendragapus obscurus). Can. F. Zool., 50, 1657-1662.

sMrTHISs, o. 1955. Zone electrophoresis in starch-gels: group variations in the serum proteins of normal human adults. Biochem. F., 61, 629-641.

sMrTHIES, o. 1959. An improved procedure for starch-gel electrophoresis: further variation in the serum proteins of normal adults. Biochem. F., $71,585-587$.

WAHLUND, s. 1928. Zusammensetzung von Populationen und Korrelationserscheinungen von Standpunkt der Vererbungslehres betrachtet. Hereditas, 11, 65-106. 